US Army Corps of Engineers ${ }_{\circledast}$

Engineer Research and

Development Center

\title{
Scour Assessment for a Bridge with Limited Site Data: Bridge 00B06, Milan Army Ammunition Plant, Tennessee
}

Sheila M. Arias-Román and Deborah Suazo-Dávila

April 2019

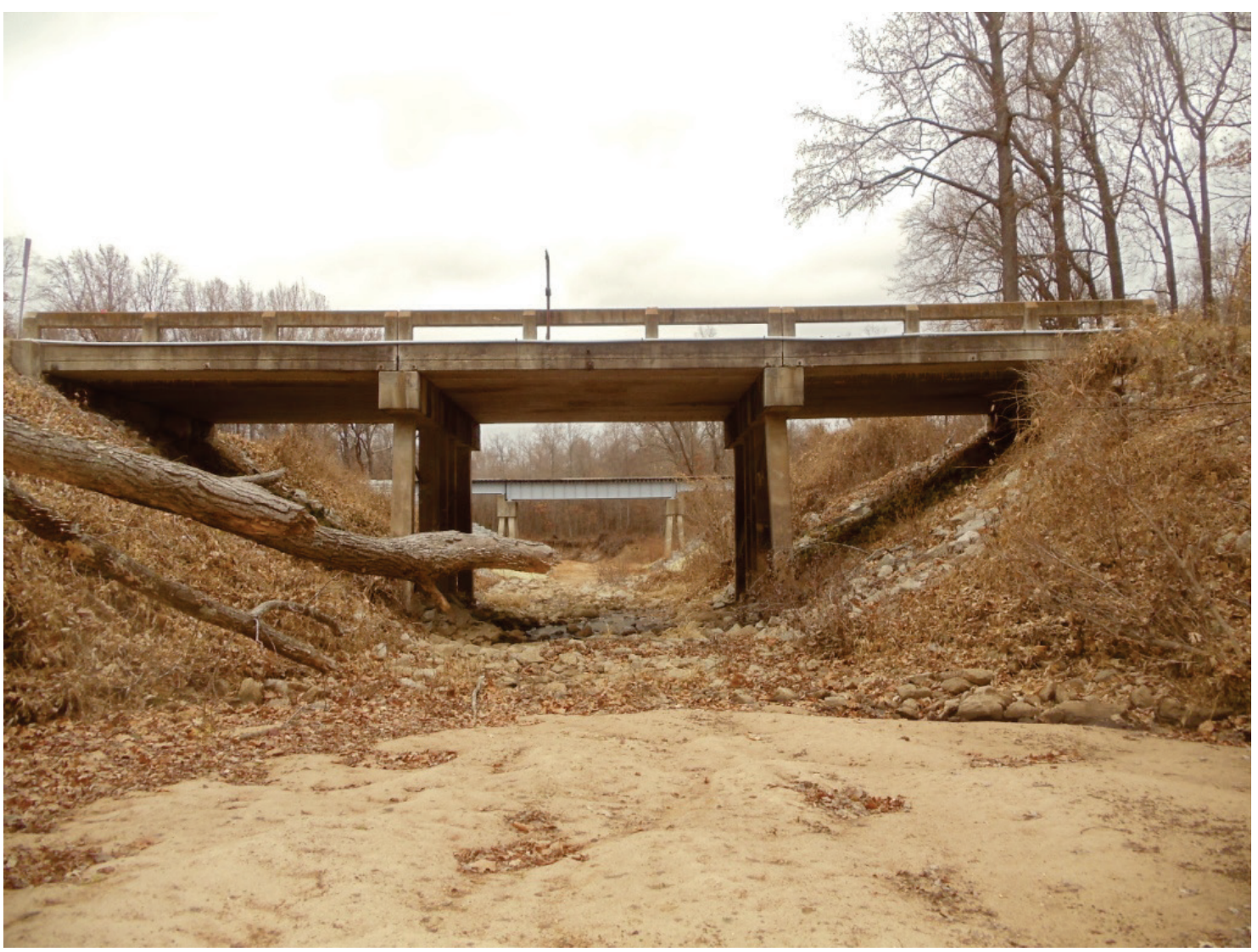


The U.S. Army Engineer Research and Development Center (ERDC) solves the nation's toughest engineering and environmental challenges. ERDC develops innovative solutions in civil and military engineering, geospatial sciences, water resources, and environmental sciences for the Army, the Department of Defense, civilian agencies, and our nation's public good. Find out more at www.erdc.usace.army.mil.

To search for other technical reports published by ERDC, visit the ERDC online library at http://acwc.sdp.sirsi.net/client/default. 


\section{Scour Assessment for a Bridge with Limited Site Data: Bridge 00B06, Milan Army Ammunition Plant, Tennessee}

Sheila M. Arias-Román and Deborah Suazo-Dávila

Geotechnical and Structures Laboratory

U.S. Army Engineer Research and Development Center

3909 Halls Ferry Road

Vicksburg, MS 39180

Final report

Approved for public release; distribution is unlimited.

Prepared for Headquarters, Installation Management Command (IMCOM)

2405 Gun Shed Road

Fort Sam Houston, TX 78234-1223

Under Project Number 154349 


\section{Abstract}

In 1991, the Federal Highway Administration (FHWA) issued the Technical Advisory 5140.23 that required all bridge owners to evaluate existing bridges for potential failure due to scour. Scour is the engineering term used to describe the natural process that results in the removal of sediment from around a bridge's structure, such as abutment walls and piers, and from the bottom and sides of the stream bed due to the flow of water. This project is an assessment of a U.S. Army bridge that crosses a waterway to determine the degree of scour vulnerability and scour depth. The purpose of this study is to develop analytical calculations using acquired data to determine scour depth based on a rapid scour assessment of an existing bridge at Milan Army Ammunition Plant at Milan, TN. The scour assessment was conducted by using the Rapid Estimation Method for Limited Site Data developed by the U.S. Geological Survey. This method allows an estimate of the scour depth to be made in a timeeffective manner by using data that can be easily collected or estimated during a brief bridge site visit. This report provides an explanation of the method used to obtain scour-depth estimates and an analytical assessment for vulnerabilities and risk of failure due to scour caused by floods in the magnitude of a 100-year event with limited available data.

DISCLAIMER: The contents of this report are not to be used for advertising, publication, or promotional purposes. Citation of trade names does not constitute an official endorsement or approval of the use of such commercial products. All product names and trademarks cited are the property of their respective owners. The findings of this report are not to be construed as an official Department of the Army position unless so designated by other authorized documents. 


\section{Contents}

Abstract................................................................................................................................... if

Figures and Tables.............................................................................................................iv

Preface ............................................................................................................................. V

Unit Conversion Factors................................................................................................... vi

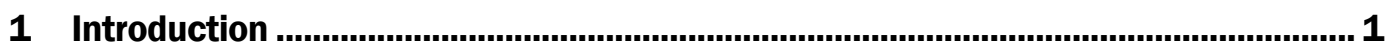

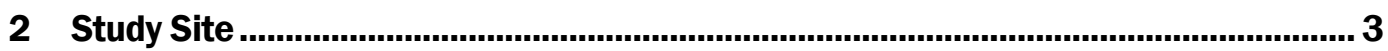

3 Rapid Estimation Method ....................................................................................... 5

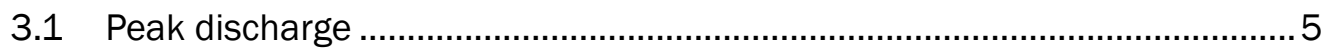

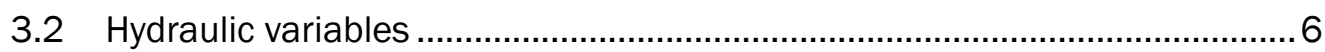

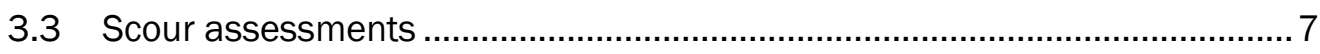

4 Scour Estimation for Bridge 00B06 ..................................................................11

5 Conclusion and Recommendations.................................................................15

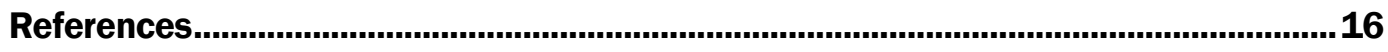

Appendix A: Bridge 00B06 Detailed Sketches ............................................................ 17 


\section{Figures and Tables}

\section{Figures}

Figure 1. Aerial view of Bridge 00B06 at Milan, TN .......................................................... 3

Figure 2. Elevation view of Bridge 00B06 at Milan, TN ..................................................... 4

Figure 3. Typical water surface profile during the 100-years rainfall event. Definition sketch of average main channel flow depth at the approach section (Y1) and at the contraction section (Y2) and the difference in water surface elevation $(\Delta \mathrm{h})$

Figure 4. General sketch of the upstream approach section for determining the widths and depths

Figure 5. Historical channel profiles for the upstream section of the bridge ..................... 14

Figure 6. Historical channel profiles for the downstream section of the bridge ................. 14

\section{Tables}

Table 1. Scour depth estimates for Bridge 00B06 at Milan, TN 


\section{Preface}

This study was conducted for Headquarters, Installation Management Command (IMCOM) Army Transportation Infrastructure Inspection Program (ATIIP) under the Bridge Safety Program Scour Evaluation and Structure Risk Analysis. The IMCOM ATIIP Program Manager was Mr. Michael R. Andres.

The work was performed by the Structural Engineering Branch (GSS) of the Geosciences and Structures Division (GS), U.S. Army Engineer Research and Development Center, Geotechnical and Structures Laboratory (ERDC-GSL). At the time of publication, Ms. Mariely MejiasSantiago was Acting Chief, CEERD-GSS; and Mr. James L. Davis was Chief, CEERD-GS. The Deputy Director of ERDC-GSL was Mr. Charles W. Ertle II, and the Director was Mr. Bartley P. Durst.

COL Ivan P. Beckman was the Commander of ERDC, and Dr. David W. Pittman was the Director. 


\section{Unit Conversion Factors}

\begin{tabular}{|l|c|l|}
\hline Multiply & By & To Obtain \\
\hline cubic feet & 0.02831685 & cubic meters \\
\hline degrees (angle) & 0.01745329 & radians \\
\hline degrees Fahrenheit & $($ F-32)/1.8 & degrees Celsius \\
\hline feet & 0.3048 & meters \\
\hline inches & 0.0254 & meters \\
\hline miles (US statute) & $1,609.347$ & meters \\
\hline square feet & 0.09290304 & square meters \\
\hline square miles & $2.589998 \mathrm{E}+06$ & square meters \\
\hline
\end{tabular}




\section{Introduction}

In the United States, $80 \%$ of all bridges were built over waterways that are constantly adjusting their natural geomorphology (Lagasse et al. 2012). These bridges are subjected to extreme changes in width, depth, and sediment transport if built over active streams. Those changes can cause severe erosion problems affecting the structural integrity of the bridge's foundation, including structural failures. A significant number of these failures can occur even on a well-designed structure that has the capacity to withstand the design traffic loads.

Several researchers have suggested that stream flood conditions are one of the leading causes of bridge failures (Murillo 1987; Lagasse et al. 2007; Johnson and Whittington 2011). Intense floods can cause the stream to overflow the bridge, increasing the water velocity and producing severe hydraulic forces that can affect the bridge's foundation. The interaction of these forces with the streambed material can result in the removal of large amounts of streambed sediment that acts as part of the foundation soil strength that supports the structure. In the engineering profession, this process is known as bridge scour and has become a noteworthy concern in the United States, since any bridge over a waterway is susceptible to experiencing critical floods capable of scouring the bed material.

The total scour at a highway structure consists of three primary components: local scour, long-term streambed elevation changes, and contraction scour. The local scour occurs when the upstream flow is obstructed by a bridge's structure, such as abutment walls and pier columns. The obstruction generates forces that can remove the bed material surrounding these structures. Contraction scour refers to the reduction in the elevation of the channel bed across the bridge opening when the cross-sectional area of the flow is contracted. The long-term scour component occurs when the stream channel elevation over time is degraded (reduced) or aggraded (increased) due to natural causes or consequences of human alterations or activities.

Since most of the existing bridges in the United States have suffered diverse failures, the Federal Highway Administration (FHWA) issued Technical Advisory T5140.23, which requires that every bridge in the 
nation be evaluated and analyzed not only for structural capacity but also for the structure-stream interaction (FHWA 1991). In this technical advisory, FHWA provides guidance for bridge scour and stream stability analyses and allows federal and state agencies to develop their own scourevaluation programs to address those conditions with respect to hydrology, geomorphology, and bridge design practices.

Bridge scour evaluation consists of the engineering assessment of the scour vulnerability of existing bridges and the selection and design of countermeasures to make scour-vulnerable bridges safe (Richardson 1996). The U.S. Army Bridge Scour Management Program was developed in accordance with National Bridge Inspection Standards (NBISs) and FHWA guidance (Suazo et al. 2013). This program is comprised of two main phases: a qualitative assessment and a quantitative analysis. In a Level I qualitative assessment, bridges are visually inspected in order to identify potential scour. The bridge scour depth is determined in the Level II quantitative assessment that requires the application of the hydrologic processes, hydraulic studies, and sediment transport of the stream. There are many useful methods to determine the magnitude of the bridge scour depth, but most of these methods involve knowledge of information and data that are difficult to obtain or not available for the specific bridge site. Therefore, the U.S. Geological Survey (USGS) developed a method that could estimate scour depth based on limited site data. The method is better known as the Rapid-Estimation Method for Assessing Scour at Highway Bridges Based on Limited Site Data (Holnbeck and Parrett 1997).

The U.S. Army Engineer Research and Development Center (ERDC) Bridge Inspection Team is responsible for performing scour evaluations for U.S. Army installation bridges. As part of this assessment, the ERDC team determines the quantitative scour depths for structures in the inventory with evidence of past scour. However, the hydrologic, river hydraulics, and geomorphology data are not available for many of the bridges. As a consequence, the purpose of this study is to develop analytical calculations using acquired data to determine scour depth based on a rapid scour assessment for an existing bridge that crosses Wolf Creek at Milan Army Ammunition Plant at Milan, TN. The purpose of the evaluation is to predict scour depths due to floods in the magnitude of a 100-year event with limited available data. This report provides an explanation of the method used to obtain scour-depth estimates and an analytical assessment for vulnerabilities and risk of failure due to scour. 


\section{Study Site}

The scour assessment was conducted at facility number ooBo6 at Milan Army Ammunition Plant (MAAP) at Milan, TN. Bridge ooBo6 (Figure 1) over the Wolf Creek was identified in a Level I evaluation with scour problems since it is over a scourable stream. The bridge location is shown in Figure 1. The approximately 76 -ft-long bridge is composed of three 25$\mathrm{ft}$-long concrete slabs and is $28 \mathrm{ft}$ wide, as shown in Figure 2. Detailed sketches of the bridge are provided in Appendix A.

Figure 1. Aerial view of bridge 00B06 at Milan, TN.

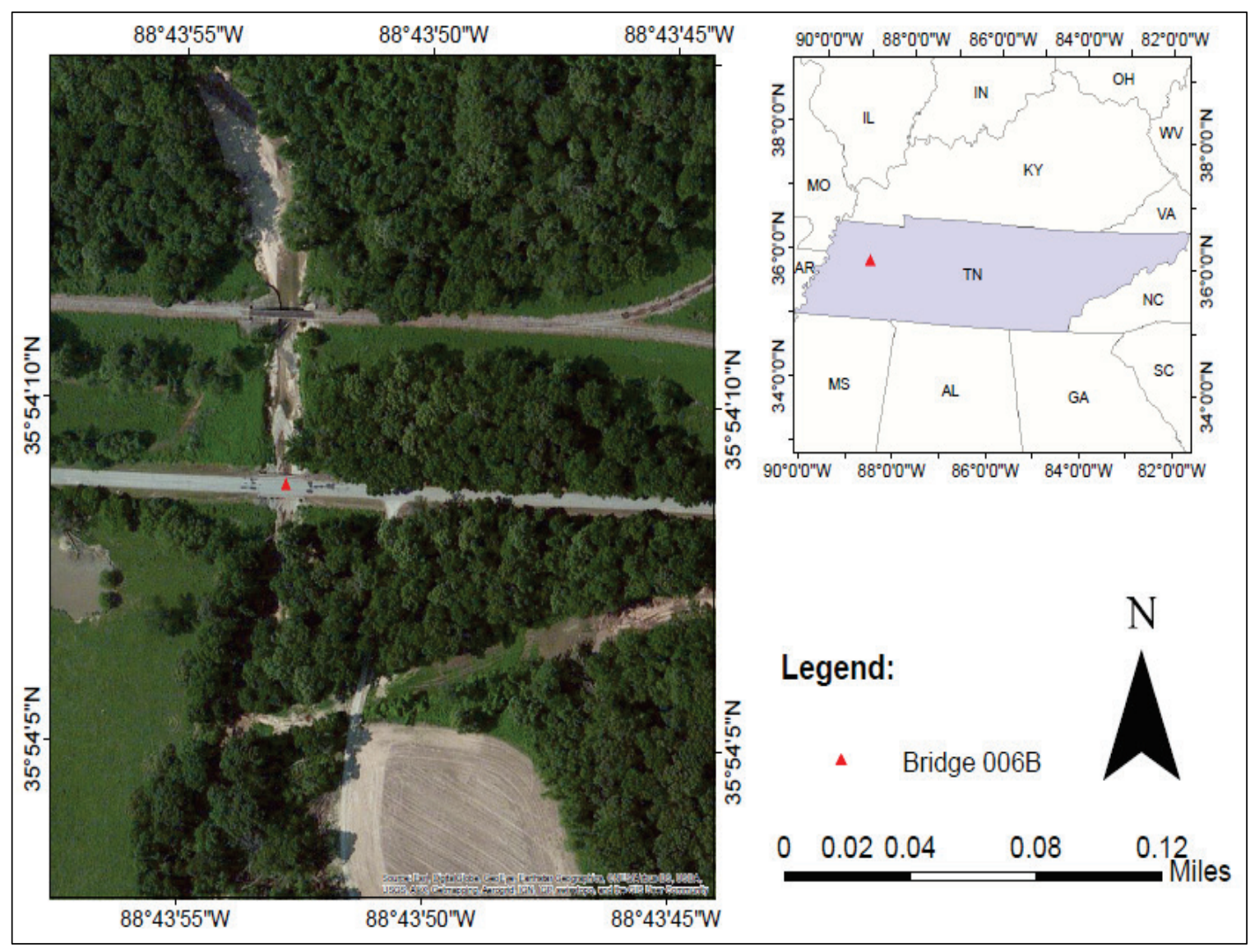


Figure 2. Elevation view of Bridge 00B06 at Milan, TN.

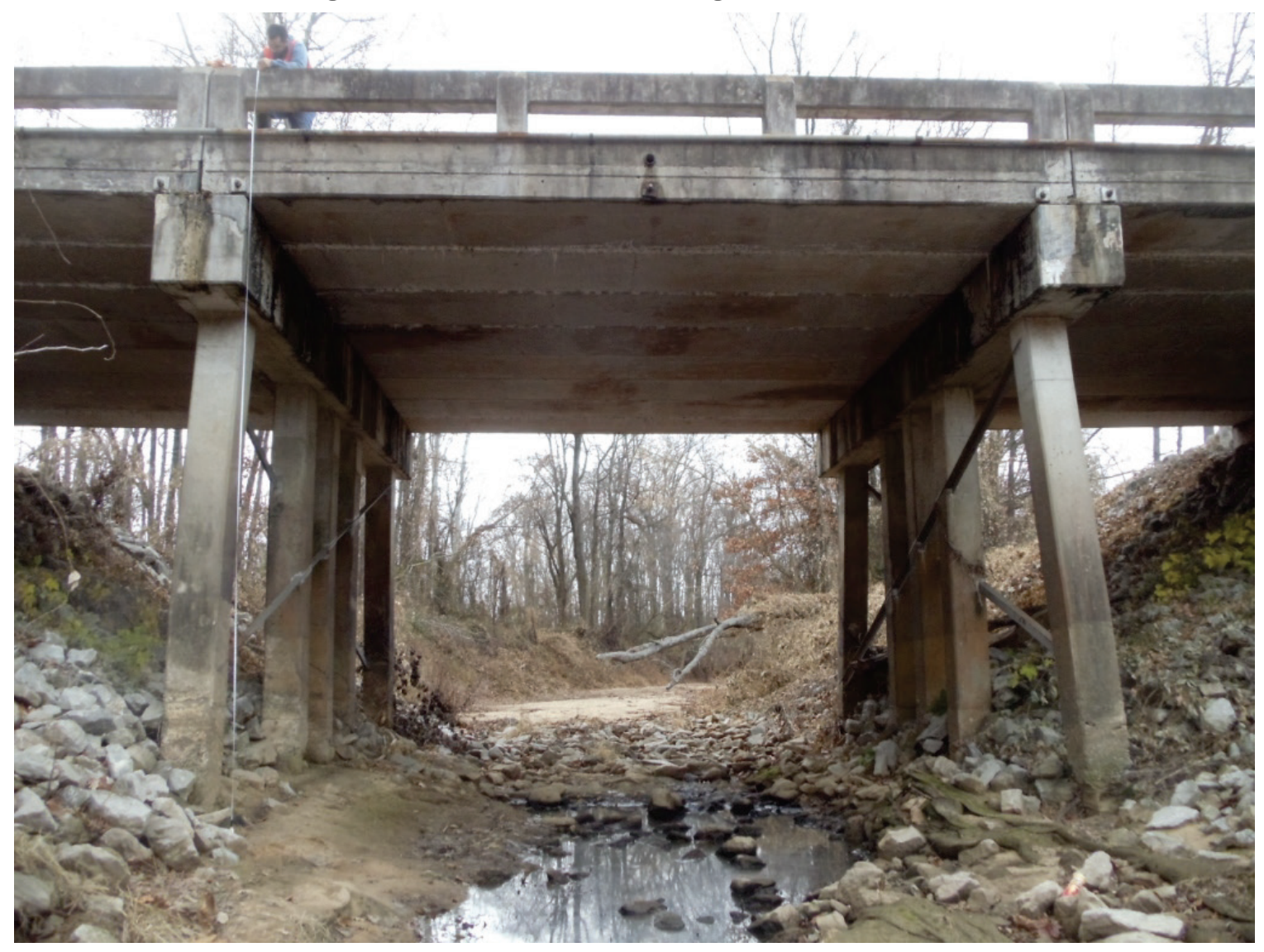




\section{Rapid Estimation Method}

The quantitative evaluation was conducted by using the rapid estimation method developed by the USGS in 1997. A detailed explanation of this method with the assumptions, capabilities, and limitations is provided by Holnbeck and Parrett (1997). This method allows an estimate of the scour depth to be made in a time-efficient manner by using data that can be easily collected or estimated during a brief bridge site visit. Even though there are many methods for determining scour components, this method was chosen to evaluate this bridge since many similar bridges located over streams that do not have the required data needed to perform a detailed Level 2 assessment are evaluated in that document. In order to use this rapid estimation assessment, it was necessary to determine the peak discharge for a 100-year rainfall event, the 100-year and average channel flow velocities, flow depths, and unit discharge. Once these data are determined, the next step is to estimate the scour components by using the equations provided by the method.

\subsection{Peak discharge}

The USGS manages an extensive network of flow gauges located at many streams across the nation. However, bridge ooBo6 does not have a gauge installed and is considered an ungauged site. Consequently, the historical flow data necessary to perform a flood-frequency analysis is unavailable. The flood discharge for the stream that passes under the bridge was estimated by using regional flood-frequency equations developed by the USGS for estimating the peak discharge at ungauged sites in Tennessee.

Weaver and Gamble (1993) documented the development of the required discharge equations. The equations were developed by using peak discharge data from 304 gauging stations and depend on the drainage area. Since the rapid estimation method is developed for the peak discharge corresponding to a 100-year recurrence, the equation that applies to the bridge site is

$$
Q_{100}=905 D A^{0.595}
$$

where

$Q_{100}=$ magnitude of the flood, in $\mathrm{ft} 3 / \mathrm{s}$

$D A=$ drainage area of the bridge, in $\mathrm{mi}^{2}$ 


\subsection{Hydraulic variables}

The hydraulics factors are the principal items responsible for the erosion around the structure's components. The equations developed in the rapid estimation method depend on several hydraulic parameters, such as the flow velocity and flow depths. The main parameter required for determining the necessary hydraulic factors is the channel flow. Once this variable has been determined, the other parameters needed to estimate the scour components are calculated.

The average main channel flow velocity is obtained by dividing the peak discharge by the total flow area at the bridge. Nevertheless, for the rapid estimation method, the USGS developed a best-fit regression equation to calculate the flow velocity at the bridge. This equation establishes a comparative relationship between the discharge and the width of the bridge and is a function of the unit discharge.

$$
V=2.07 q^{0.322}
$$

where

$$
\begin{aligned}
& V=\text { average main channel velocity, in } \mathrm{ft} / \mathrm{s} \\
& q=\text { unit discharge, in } \mathrm{ft} 3 / \mathrm{s} / \mathrm{ft}
\end{aligned}
$$

The unit discharge is obtained with the following equation.

$$
q=\frac{Q}{W_{2}}
$$

where

$$
\begin{aligned}
q= & \text { unit discharge, in } \mathrm{ft} 3 / \mathrm{s} / \mathrm{ft} \\
Q= & \text { magnitude of the flood, in } \mathrm{ft} 3 / \mathrm{s} \\
W_{2}= & \text { estimated top of flow at the downstream face of the bridge } \\
& \text { opening, in } \mathrm{ft}
\end{aligned}
$$

This equation brings a more accurate velocity result appropriate to the situation, since it considers the bridge properties.

Once the unit discharge and the velocity are calculated, the flow depths are estimated by using the equation developed in the method. These variables 
are important since the discharge effect depends on the flow depths. The following figure shows how to calculate these variables.

Figure 3. Typical water-surface profile during a 100-year rainfall event illustrating the average main channel flow depth at the approach section (Y1) and at the contraction section (Y2) and the difference in water-surface elevation $(\Delta h)$.

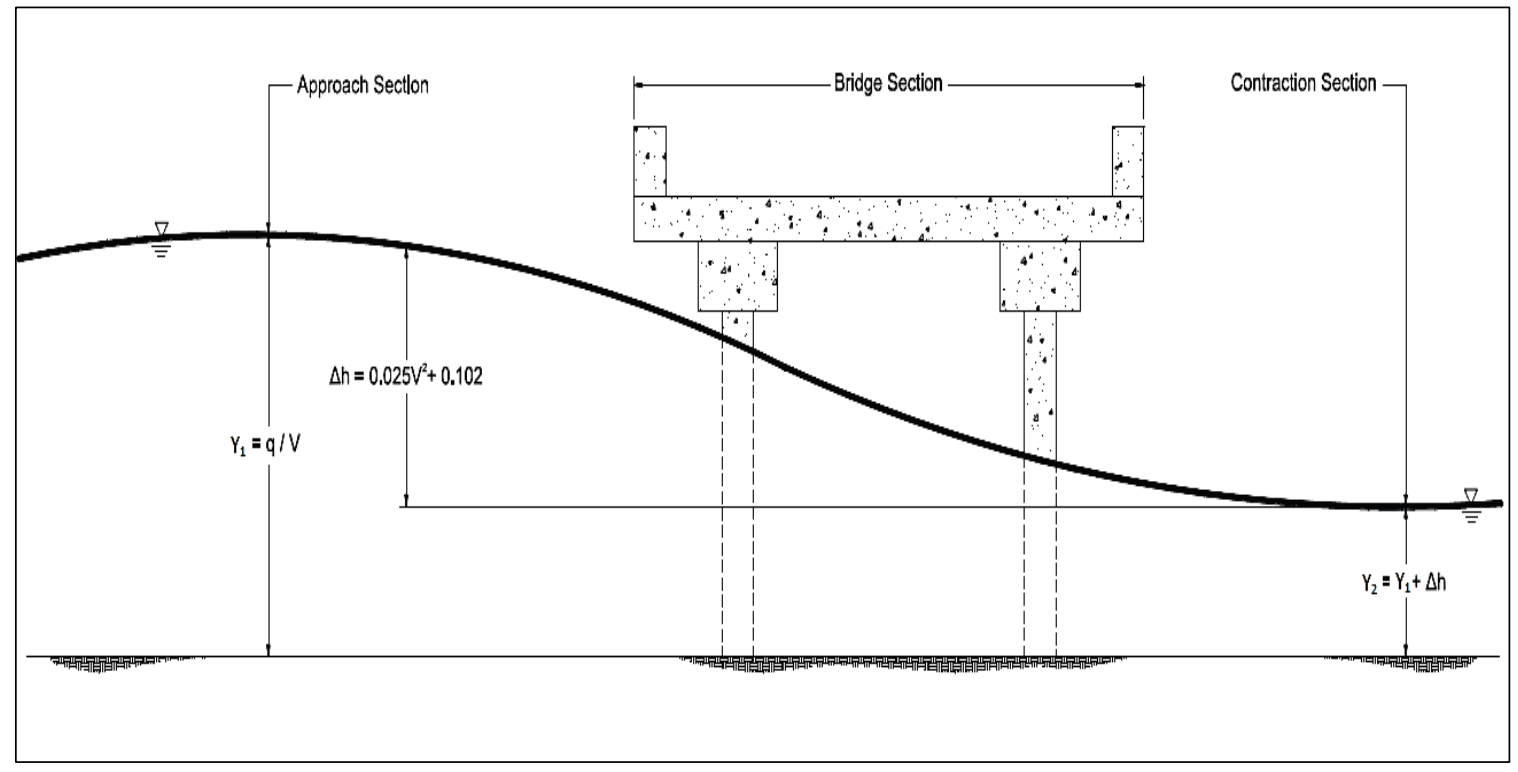

\subsection{Scour assessments}

In order to determine the contraction scour depth, it is necessary to determine whether the flow has the capacity to transport sediments (i.e., to establish the scour conditions). The scour scenario can be either livebed scour or clear-water scour. These conditions depend on the velocity at the approach section and the critical velocity of flow. When the bed material has a size less than $0.075 \mathrm{~mm}$, the likely scour scenario is live bed, since this material is likely to be transported. If the sediment diameter has a significant size and the velocity is relatively small or the channel has obstructions like vegetation or debris that prevent material transport, the scour conditions that could exist are clear water.

The scour conditions are determined by comparing the mean approach velocity with the critical velocity of flow. If the velocity at the approach is greater than the critical velocity, the scour conditions are live bed. Otherwise, the conditions are clear water since the flow velocity is insufficient for transport of streambed material. 
The mean approach velocity is obtained by dividing the peak discharge by the flow area. The area is defined by the depth at the approach section multiplied by the width of flow.

$$
V_{a}=\frac{Q}{Y_{1} W_{1}}
$$

where

$$
\begin{aligned}
V_{a} & =\text { mean approach velocity, in } \mathrm{ft} / \mathrm{s} \\
Q & =\text { magnitude of the flood, in } \mathrm{ft} 3 / \mathrm{s} \\
W_{1} & =\text { estimated width of the main channel at the approach section, } \\
& \quad \text { in } \mathrm{ft}
\end{aligned}
$$

The critical velocity of flow is obtained by using an equation developed by Neill (1968).

$$
V_{c}=11.52\left(Y_{1}^{1 / 6}\right) D^{1 / 3}
$$

where

$$
\begin{aligned}
& V_{c}=\text { critical velocity of flow, in } \mathrm{ft} / \mathrm{s} \\
& D=\text { median diameter of the streambed material, in } \mathrm{ft} \\
& Y_{1}=\text { average main channel flow depth at the approach section, in } \mathrm{ft}
\end{aligned}
$$

The USGS developed different equations in the rapid estimation method for estimating the contraction scour that depend on the scour scenario. The contraction scour is determined based on an envelope curve where the contraction scour is plotted against a contraction scour variable. The developed equations are for determining the contraction scour variable. Once this variable is calculated, the scour depth is determined from the envelope curve.

The scour conditions in the bridge site at MAAP are live bed; therefore, the corresponding equation for the contraction scour variable is

$$
\chi=\left[Y_{1}\left(\frac{W_{1}}{W_{2}}\right)-Y_{1}\right]\left[\left(\frac{n_{1}}{W_{2} Y_{1}^{2 / 3}}\right)\left(\frac{W_{L} Y_{L}^{5 / 3}}{n_{L}}+\frac{W_{R} Y_{R}^{5 / 3}}{n_{R}}\right)\right]
$$


where

$\chi=$ contraction scour variable, in $\mathrm{ft}$

$Y_{1}=$ average main channel flow depth at the approach section, in $\mathrm{ft}$

$Y_{L}=$ average depth of flow on the left overbank area at the approach section, in $\mathrm{ft}$

$Y_{R}=$ average depth of flow on the right overbank area at the approach section, in $\mathrm{ft}$

$W_{1}=$ estimated width of the main channel at the approach section, in $\mathrm{ft}$

$W_{2}=$ estimated top width of flow at the downstream face of the bridge opening, in $\mathrm{ft}$

$W_{L}=$ estimated width of flow at the left overbank area at the approach section, in $\mathrm{ft}$

$W_{R}=$ estimated width of flow at the right overbank area at the approach section, in $\mathrm{ft}$

$n_{1}=$ Manning roughness coefficient for the main channel at the approach section

$n_{L}=$ Manning roughness coefficient for the left overbank area at the approach section

$n_{R}=$ Manning roughness coefficient for the right overbank area at the approach section

Figure 4 illustrates some of the above parameters.

Figure 4. General sketch of the upstream approach section for determining the widths and depths.

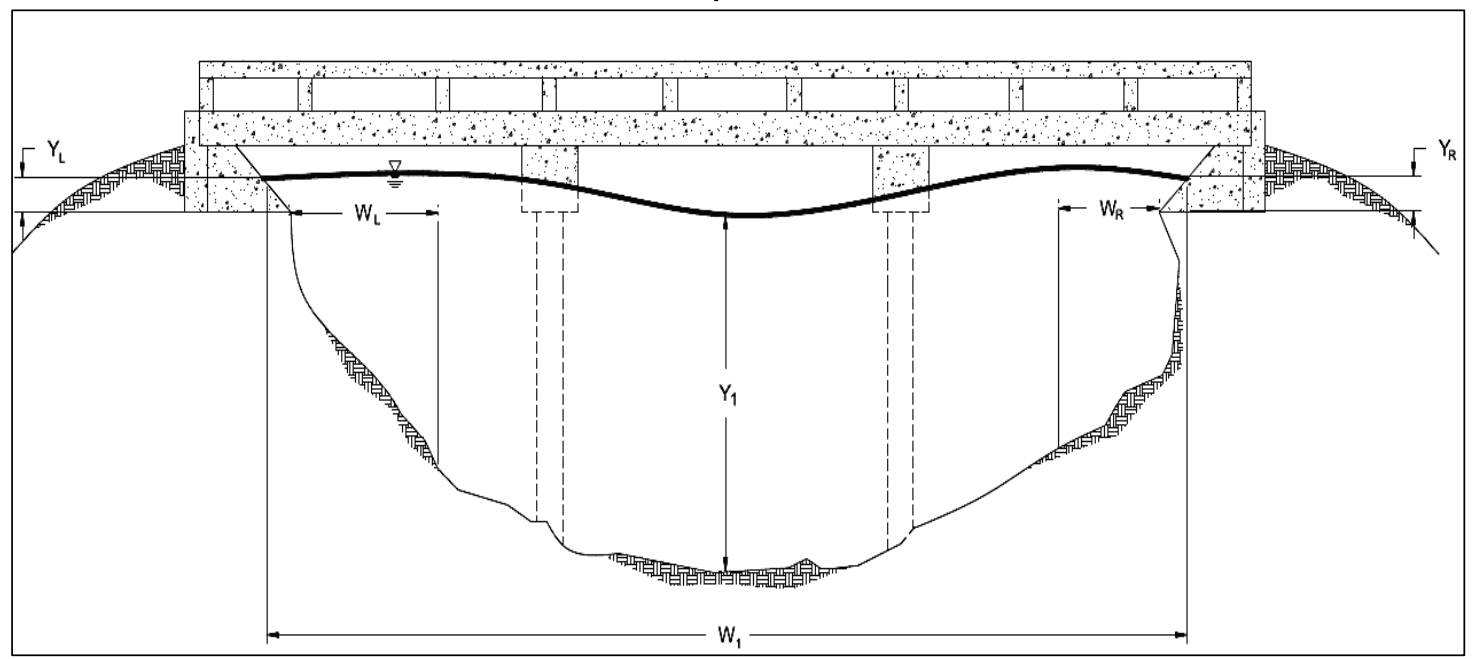


The scour depth at the pier columns was determined as the contraction scour since it requires determining a scour variable to be able to obtain the scour depth. This depth is affected by factors such as the velocity, depth of flow, and bridge structural dimensions like length and width. Another factor affecting the scour depth that is essential for the calculation is the flow angle of attack on the piers. The scour-depth magnitude will depend on the flow direction just upstream of a bridge. For this angle of attack, a correction factor that is proportional to the scour depth exists. Since the pier shapes are square for Bridge 0oBo6, this correction factor is 1 because the ratio between the pier length and pier width is also 1 . The variable needed to estimate the scour depth is obtained from an envelope curve that depends on the pier width. Once this variable is determined, the pier scour depth is estimated with the following equation.

$$
Y_{P S}=\varepsilon K_{2} F^{0.15}
$$

where

$$
\begin{aligned}
Y_{P S} & =\text { pier scour depth, in } \mathrm{ft} \\
F & =\text { Froude Number } \\
K_{2} & =\text { correction factor for the angle of attack } \\
\varepsilon & =\text { pier scour function, in } \mathrm{ft}
\end{aligned}
$$

Determining the abutment scour requires knowledge of parameters that have to be determined at the bridge site. These parameters include the width and depth of flow at the abutments and overbanks. The scour depth needs to be evaluated for both abutments since the streambed can have different behaviors at each side. The abutment scour variable is obtained from the envelope curve; then the abutment scour depth is calculated as

$$
Y_{a s}=\frac{\psi K_{1}}{0.55}
$$

where

$$
\begin{aligned}
Y_{a s} & =\text { abutment scour depth, in } \mathrm{ft} \\
\Psi & =\text { abutment scour function, in } \mathrm{ft} \\
K_{1} & =\text { correction factor for abutment shape }
\end{aligned}
$$




\section{Scour Estimation for Bridge 00B06}

The absence of the required data to perform a detailed Level II evaluation was the main reason to select another method to predict the scour depths. Therefore, the USGS Rapid-Estimation Method for Assessing Scour at Highway Bridges Bases on Limited Site Data (Holnbeck and Parrett 1997) was used for the scour estimates. The rainfall and runoff data for the bridge site were not available; therefore, the peak discharge for a 100-year recurrence was estimated by using regional flood-frequency equations developed by the USGS for ungauged watersheds in Tennessee. The discharge was determined for a 100-year-flood, as this flood event is used as the standard design threshold for all bridge construction. The stream passing through the bridge has a catchment area of about 17.89 square miles. Hence, the 100-year-flood flow is approximately 5,035 cfs.

It is expected that, in an event of a 100-year recurrence, there will be a significant removal of sediments from the bottom of the river and its surroundings since the average velocity is greater than the critical velocity. Consequently, the flow has the capacity to transport sediments from the scour holes and from the upstream section. This is mainly due to the smaller diameters of the soil particles (mostly clay), which imply that it has a greater probability of eroding easily.

In order to use the equations for determining contraction, pier and abutment scour were required for determining different hydraulic characteristics that are responsible for the elevation changes that the streambed has undergone. A summary of the estimated scour depths is in Table 1. The contraction scour depth depends on factors such as the conditions and scour scenario at the stream. The conditions vary with the rate of flow from the upstream to the downstream. After analyzing and determining the local variables and values, the magnitude of the average velocity relative to the critical velocity for the initiation of motion indicates that the scour conditions are live bed at the bridge site. 
Table 1. Scour depth estimates for Bridge 00B06 at MAAP, Milan, TN.

\begin{tabular}{ccccccc}
\hline & & & & \multicolumn{2}{c}{ Abutment Scour (ft) } \\
$\begin{array}{ccccc}\text { Recurrence } \\
\text { Interval }\end{array}$ & $\begin{array}{c}\text { Flood } \\
\text { Flow } \\
(\mathrm{cfs})\end{array}$ & $\begin{array}{c}\text { Contraction } \\
\text { Scour }(\mathrm{ft})\end{array}$ & $\begin{array}{c}\text { Pier } \\
\text { Scour } \\
(\mathrm{ft})\end{array}$ & Left & Right \\
\cline { 5 - 7 } & & 9.50 & 6.38 & 6.00 & 6.00 \\
\hline
\end{tabular}

The geometric properties of the bridge that have a great impact in the contraction scour depth are the approach, contraction, and overbank area widths. The analyzed stream has a greater flow width in the approach area than in the area where the bridge is located. As the flow space is being reduced, the velocity becomes greater to accommodate the amount of water, increasing flow. This increases the stream's potential to transport and remove more sediments and decreases the streambed elevation. The flow depths in the overbank also have a possible negative impact on the scour conditions. The obtained flow depth in the approach section is about $19 \mathrm{ft}$, making it possible that the flow has a significant height in the overbanks since both depths are proportional.

The equation developed in the method of rapid estimation to determine the pier scour is a function of the pier-scour function, the mean channel velocity, and the flow depth upstream from the pier. The width of the pier influences the results since it is used principally to determine the pier function. The developed equation is dependent on the Froude number and the coefficient of correction for the angle of attack. The pier's geometry is a square, and the flow reaches the bridge at a right angle, so the $K_{2}$ factor is 1. Besides, the method establishes that, for all square or circular piers, the length-to-width ratio is to be estimated at 1.

The average velocity obtained was approximately $8 \mathrm{ft} / \mathrm{s}$, and the obtained depth was $16 \mathrm{ft}$. With these parameters, the average pier scour depth is $6.38 \mathrm{ft}$. The geometry of the piers and the stream conditions equally affect the piers on the left and right sides; hence, the result establishes that each pier has equivalent, basically interchangeable, conditions. This depth for pier scour represents the change in elevation that the sediments around the structure could have or the depth of the scour holes as a consequence of a 100-year rainfall event. However, it can be presumed that the conditions are live bed due to soil composition and the magnitude and depth of the flow. 
The depth of scour at the abutments is affected by the flow depth at the approach section. The method assumes that the depth of the flow at each of the abutments is equal to the depth in the overbanks, but due to the geometry of the bridge and the characteristics of the overbanks, it could not be assumed this way. The depth in the approach was used for the depth of the flow at the abutments, and, based on that depth, it was estimated how high the flow would reach from the surface to the abutment.

The scour depths estimated at the bridge were compared to the historical bed elevation changes in the site. The calculated total scour depth at each bent for the 100-year flood is the sum of the contraction scour depth and the pier scour depth and for the abutments is the sum of the contraction scour depth and the abutments scour depth. Hence, the total scour depths for the piers and the abutments are $15.88 \mathrm{ft}$ and $15.5 \mathrm{ft}$, respectively. According to the results obtained, the assessed bridge has not been affected by a 100-year rainfall event. An increase in scour in the streambed at the bridge crossing has been observed in the historical channel profiles in which up to $5 \mathrm{ft}$ of total scour was present at each bent. The channel profiles for the upstream and downstream sections of the bridge crossing are shown in Figures 5 and 6, respectively. 
Figure 5. Historical channel profiles for the upstream section of the bridge.

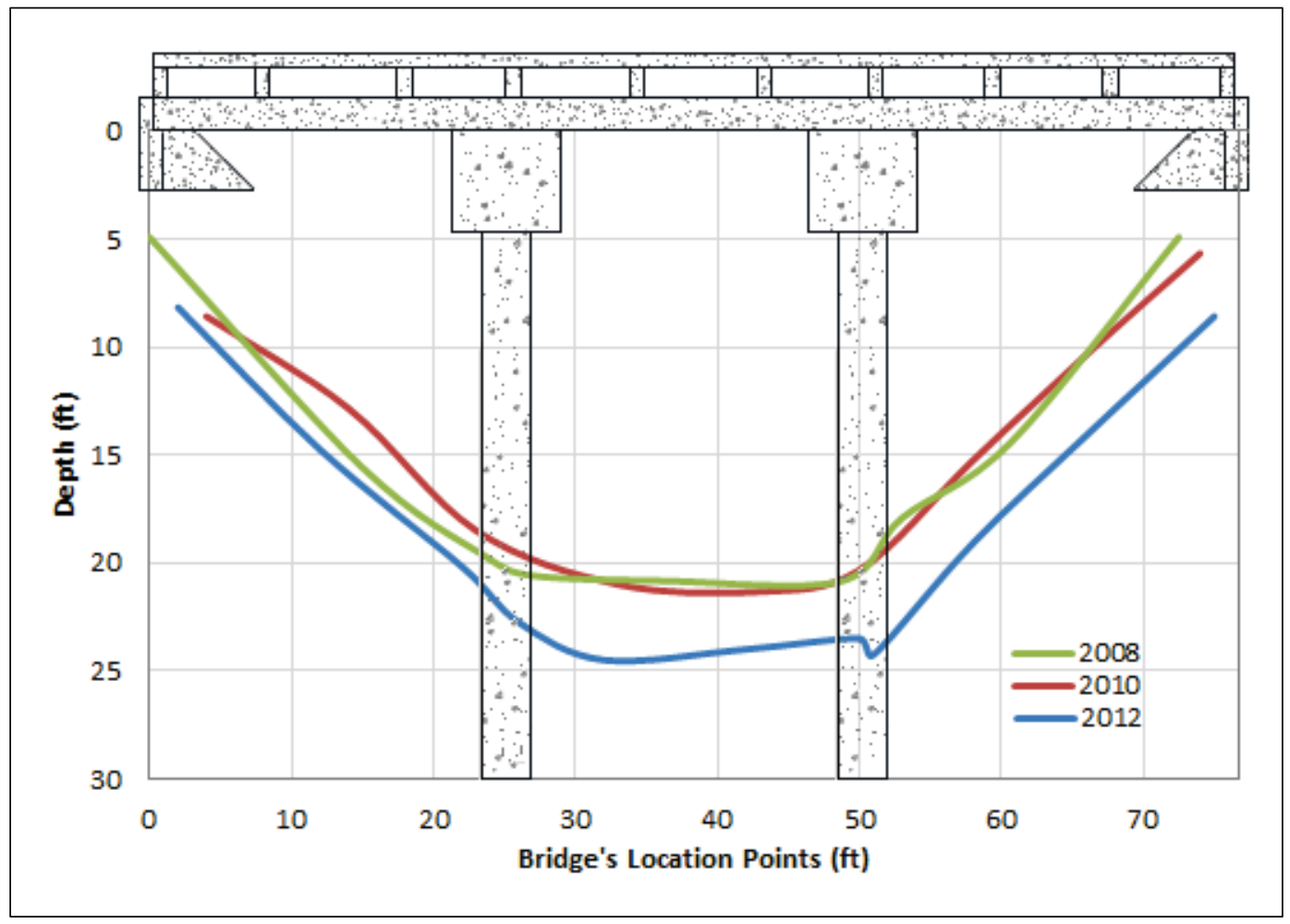

Figure 6. Historical channel profiles for the downstream section of the bridge.

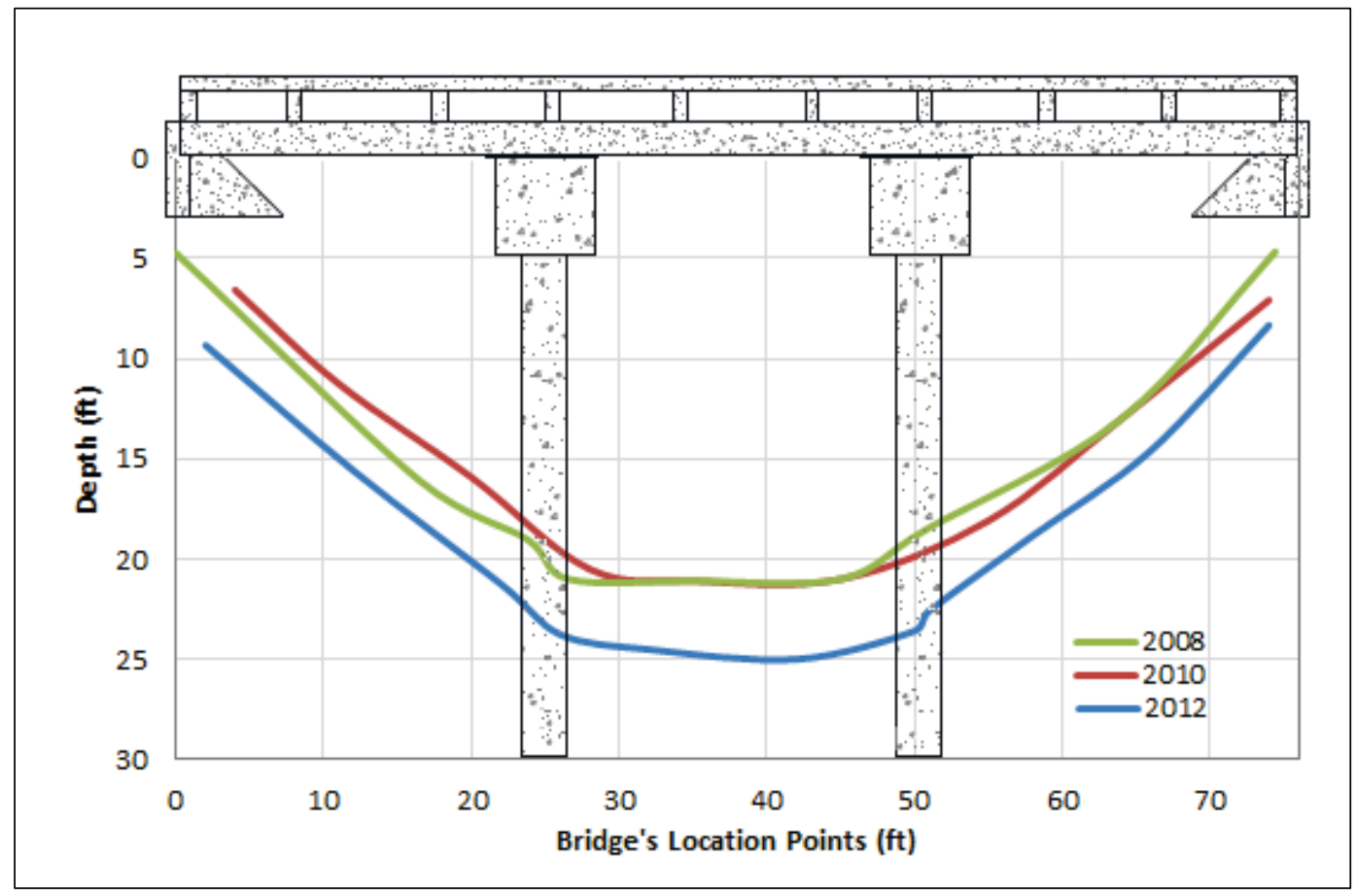




\section{Conclusion and Recommendations}

The purpose of this study was to determine scour depth corresponding to a 100-year flood event based on limited data. A rapid scour assessment was applied on an existing bridge at Milan Army Ammunition Plant at Milan, $\mathrm{TN}$, to evaluate the scour potential and the capacity of the foundation to withstand future flood events. The absence of the necessary information, such as hydrologic data, detailed river hydraulics, and geomorphology characteristics of the site, was the limiting factor for the scour-depth computations. Hence, a rapid estimation method was used to compute the contraction, pier, and abutment scour depths for the assessed bridge. The scour assessment requires a reliable estimation of flow; hence, the flood discharge for the stream was estimated by using regional flood-frequency equations developed by the USGS. This flow was used to determine the scour depth at the bridge site and provide a general knowledge of the bridge's condition. It can be assumed that the USGS rapid estimation method provides conservative results, considering that the analysis is designed to have that approach. Furthermore, there are no field data available to accomplish more exact scour-depth results at the bridge site. The scour estimates are the change in elevation that the stream bed can have in the contraction area, or the change in elevation of the sediments that surround the bridge structure, either the pier columns or the abutment walls.

The USGS Rapid Estimation Method is a useful tool that allows the approximation of each of the scour components in places where the necessary data to utilize the more advanced methods of evaluation are not available. This method provides equations with less complicated variables that can be determined in the field or by using profile sections of the bridge. Although the method allows for the determination of the scour components, such as contraction and local scour, it is not feasible to be utilized in streams where the change in elevation or the erosion is occurring due to natural causes like aggradation and degradation scour. This scour component has a completely different behavior from the other two, and the equations developed in the method of rapid estimation do not apply to this case. 


\section{References}

Federal Highway Administration (FHWA). 1991. Evaluating scour at bridges. Technical Advisory 5140.23.Washington, DC: U.S. Department of Transportation.

Holnbeck, S. R., and C. Parrett. 1997. Method for rapid estimation of scour at highway bridges based on limited site data. Bozeman, MT: U.S. Geological Survey.

Johnson, P. A., and R. M. Whittington. 2011. Vulnerability-based risk assessment for stream instability at bridges. Journal of Hydraulic Engineering 137(10):12481256.

Lagasse, P. F., P. E. Clopper, L. W. Zevenbergen, and L. W. Girard. 2007. Countermeasures to protect bridge piers from scour. NCHRP Report 593. Washington, DC: National Cooperative Highway Research Program, Transportation Research Board of the National Academies.

Lagasse, P. F., L. W. Zevenbergen, W. J. Spitz, and L. A. Arneson. 2012. Stream stability at highway structures. 4th ed. FHWA-HIF-12-004 Hydraulic Engineering Circular No. 20. Fort Collins, CO: Federal Highway Administration.

Murillo, Juan A. 1987. The scourge of scour: Civil engineering. American Society of Civil Engineers 57(7):66-69.

Neill, C. R. 1968. Note on initial movement of coarse uniform bed material. Journal of Hydraulic Research 17(2):247-249.

Richardson, E. V. 1996. Historical development of bridge scour evaluations. In Proceedings of North American Water and Environment Congress \& Destructive Water, 22-28 June, Anaheim, CA, ed. Chenchayya Bathala. New York: American Society of Civil Engineers.

Suazo, Deborah, Walter Silva, and Jorge Rivera. 2013. Methodology for scour evaluation of U.S. Army installation bridges. ERDC TR-13-1. Vicksburg, MS: U.S. Army Engineer Research and Development Center.

Weaver, J. D., and C. R. Gamble. 1993. Flood-frequency of streams in rural basin of Tennessee. Investigations Report. Reston, VA: U.S. Geological Survey. 


\section{Appendix A: Bridge 00B06 Detailed Sketches}

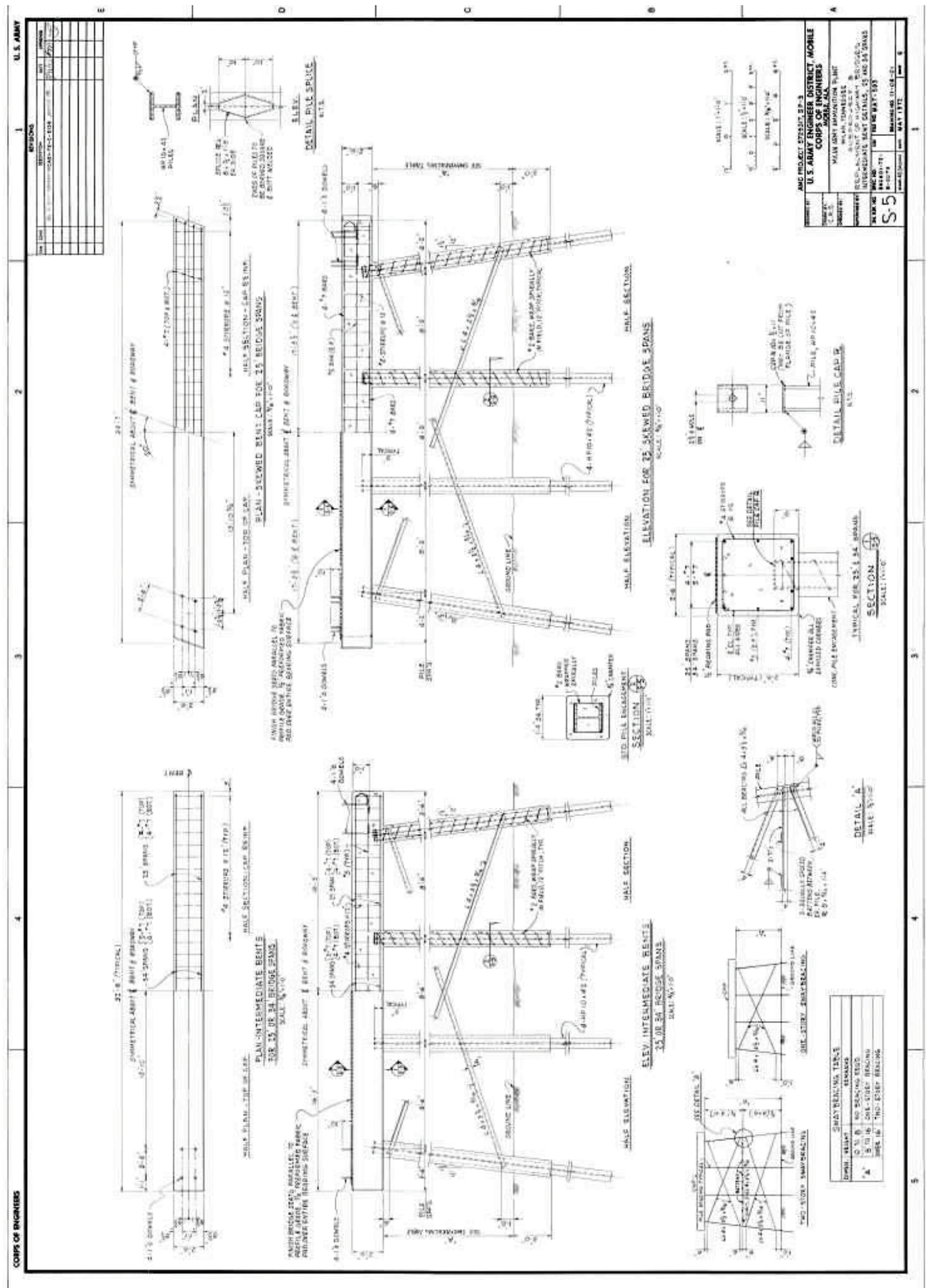




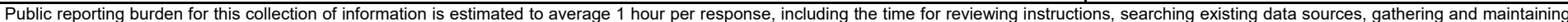

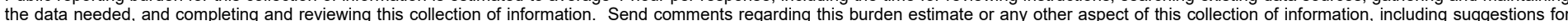

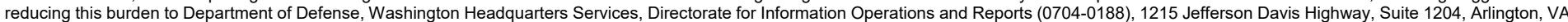

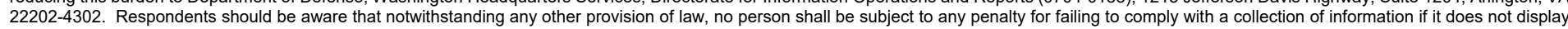
a currently valid OMB control number. PLEASE DO NOT RETURN YOUR FORM TO THE ABOVE ADDRESS.
1. REPORT DATE (DD-MM-YYYY) 2. REPORT TYPE
3. DATES COVERED (From - To) April 2019 Final

\section{TITLE AND SUBTITLE}

Scour Assessment for a Bridge with Limited Site Data: Bridge 00B06, Milan

Army Ammunition Plant, Tennessee

5a. CONTRACT NUMBER

5b. GRANT NUMBER

5c. PROGRAM ELEMENT NUMBER

6. AUTHOR(S)

Sheila M. Arias-Román and Deborah Suazo-Dávila

5d. PROJECT NUMBER

154349

5e. TASK NUMBER

5f. WORK UNIT NUMBER

7. PERFORMING ORGANIZATION NAME(S) AND ADDRESS(ES)

8. PERFORMING ORGANIZATION REPORT NUMBER

Geotechnical and Structures Laboratory

U.S. Army Engineer Research and Development Center

ERDC/GSL TR-19-17

3909 Halls Ferry Road

Vicksburg, MS 39180-6199

\section{SPONSORING / MONITORING AGENCY NAME(S) AND ADDRESS(ES)}

Headquarters, Installation Management Command

2405 Gun Shed Road

Fort Sam Houston, TX 78234-1223

10. SPONSOR/MONITOR'S ACRONYM(S)

IMCOM

11. SPONSOR/MONITOR'S REPORT NUMBER(S)

\section{DISTRIBUTION / AVAILABILITY STATEMENT}

Approved for public release; distribution is unlimited.

\section{SUPPLEMENTARY NOTES}

\section{ABSTRACT}

In 1991, the Federal Highway Administration (FHWA) issued the Technical Advisory 5140.23 that required all bridge owners to evaluate existing bridges for potential failure due to scour. Scour is the engineering term used to describe the natural process that results in the removal of sediment from around a bridge's structure, such as abutment walls and piers, and from the bottom and sides of the stream bed due to the flow of water. This project is an assessment of a U.S. Army bridge that crosses a waterway to determine the degree of scour vulnerability and scour depth. The purpose of this study is to develop analytical calculations using acquired data to determine scour depth based on a rapid scour assessment of an existing bridge at Milan Army Ammunition Plant at Milan, TN. The scour assessment was conducted by using the Rapid Estimation Method for Limited Site Data developed by the U.S. Geological Survey. This method allows an estimate of the scour depth to be made in a time-effective manner by using data that can be easily collected or estimated during a brief bridge site visit. This report provides an explanation of the method used to obtain scour-depth estimates and an analytical assessment for vulnerabilities and risk of failure due to scour caused by floods in the magnitude of a 100-year event with limited available data.

\section{SUBJECT TERMS}

Bridge collapses

Bridge Scour

16. SECURITY CLASSIFICATION OF:

\begin{tabular}{|l|l|}
\hline a. REPORT & b. ABSTRACT \\
Unclassified & Unclassified \\
\hline
\end{tabular}

Rapid Scour Estimation Method

Scour (hydraulic engineering)

Sediment transport

17. LIMITATION
OF ABSTRACT

Bridges

Military bases

Scour at bridges

\section{NUMBER $19 a$. NAME OF RESPONSIBLE OF PAGES}

26 19b. TELEPHONE NUMBER (include area code) 